\title{
Faktor-faktor yang Berhubungan dengan Kejadian Stunting pada Balita
}

\author{
Asweros Umbu Zogara1, Maria Goreti Pantaleon ${ }^{2}$ \\ 1,2Jurusan Gizi, Politeknik Kesehatan Kementerian Kesehatan Kupang, Kota Kupang \\ Jl. RA Kartini I, Kelapa Lima, Kota Kupang \\ Email: 'eroz.zogara@gmail.com, 2margotepunk@gmail.com
}

\begin{abstract}
Abstrak
Masa balita merupakan periode yang sangat penting bagi kelangsungan hidup ke depannya. Oleh karena itu, perlu diperhatikan kondisi kesehatan, termasuk status gizi balita. Masalah stunting memiliki dampak yang besar bagi masa depan balita. Penelitian ini bertujuan untuk menganalisis hubungan antara faktor orangtua dan kejadian stunting pada balita di Desa Kairane dan Desa Fatukanutu. Penelitian dilaksanakan di Desa Kairane dan Desa Fatukanutu, Kecamatan Amabi Oefeto, Kabupaten Kupang pada bulan September sampai Desember 2019. Desain studi cross sectional digunakan dalam penelitian ini. Sampel penelitian berjumlah 176 balita dan data dianalisis menggunakan uji chi square. Hasil penelitian menunjukkan faktor orang tua yang berhubungan dengan kejadian stunting adalah pendidikan ayah (Pvalue=0,035) dan ibu (Pvalue=0,03I), jumlah anggota keluarga (Pvalue=0,008), dan pengetahuan gizi ibu (Pvalue=0,002). Sedangkan pekerjaan ayah (Pvalue= 0,233) dan pekerjaan ibu (Pvalue $=0,895)$ tidak berhubungan dengan kejadian stunting. Asupan zat gizi yang berhubungan dengan kejadian stunting, yaitu asupan protein (Pvalue=0,002) dan lemak (Pvalue=0,017). Sedangkan asupan karbohidrat tidak berhubungan dengan kejadian stunting (Pvalue=0,687). Perlu dilakukan intervensi gizi untuk memperbaiki status stunting pada balita, antara lain peningkatan pengetahuan gizi ibu dan asupan makanan yang bergizi.
\end{abstract}

Kata Kunci : Asupan zat gizi, balita, faktor orang tua, stunting

\begin{abstract}
The first five years of a child's life are fundamentally important to their future. Therefore, it is necessary to pay attention to the health condition, including their nutritional status. Stunting has a big impact for the future of children under the age of five years. The aim of this study is to analyze the correlation between parental factors and nutrients intake with stunting incidence on children under five years old in Desa Kairane and Desa Fatukanutu. This research was implemented in Desa Kairane and Desa Fatukanutu, Kecamatan Amabi Oefeto, Kabupaten Kupang on September until December 2019. This study used cross sectional design. The sample of this research was about 176 children under five years old and analyzed by using chi square test. The result showed parental factors were correlated with stunting incidence were fathers education $(P v a l u e=0,035)$ and mothers education (Pvalue=0,03I), the number of family members (Pvalue $=0,008$ ), and maternal nutrition knowledge ( $P$ value $=0,002$ ). While father's occupation (Pvalue $=0,233$ ) and mother's occupation (Pvalue $=0,895)$ were not correlated with stunting incidence. The nutrients intake that correlated with stunting incidence were protein (Pvalue $=0,002)$ and lipid (Pvalue $=0,017)$. While carbohydrate intakes was not correlated with stunting incidence (Pvalue=0,687). Nutritional intervention needs to be done to improve the status of stunting in children under five, including increasing maternal nutrition knowledge and nutritious food intake.
\end{abstract}

Keywords: Nutrients intake, children under five, parental factors, stunting 


\section{Pendahuluan}

Stunting (tubuh pendek) pada balita merupakan manifestasi dari kekurangan zat gizi kronis, baik saat pre- maupun postnatal. Stunting merupakan hambatan pertumbuhan yang diakibatkan oleh, selain kekurangan asupan zat gizi, juga adanya masalah kesehatan. Keadaan stunting dipresentasikan dengan nilai z-score panjang badan atau tinggi badan menurut umur <-2 SD. ${ }^{1}$ Masalah stunting memiliki dampak yang besar bagi masa depan balita. Stunting dapat mengurangi kelangsungan hidup balita, prestasi sekolah, dan produktivitas ekonomi. Anak stunting saat dewasa akan berisiko menghasilkan sumber daya manusia yang kurang berkualitas. ${ }^{2}$ Dalam populasi yang sehat, kurang lebih 2,5\% anak yang memiliki zscore <2 SD. Apabila melebihi 2,5\% maka mengindikasikan adanya masalah pertumbuhan. ${ }^{3}$

Intervensi perlu dilakukan untuk mencegah terjadinya stunting. Intervensi dapat dimulai dengan 1000 Hari Pertama Kehidupan (1000 HPK). 1000 HPK dimulai saat ibu hamil dan 2 tahun pertama kehidupan. Intervensi gizi pada 1000 HPK akan berdampak besar karena pertumbuhan dan perkembangan anak terjadi dengan sangat cepat. ${ }^{4}$ Setelah melewati periode 1000 HPK, anak tetap harus diberikan perhatian oleh orang tua melalui pemberian makanan bergizi dan menjaga kondisi lingkungan yang sehat. Penelitian di Zimbabwe menunjukkan pemberian makan bergizi dapat menurunkan angka stunting sebesar $8 \%,{ }^{2}$ sedangkan penelitian di Burkino Faso menjelaskan bahwa lingkungan yang tidak sehat berhubungan dengan kejadian stunting pada balita. ${ }^{5}$

Peran orang tua sangat besar dalam pencegahan dan penanggulangan masalah stunting. Hal ini dikarenakan balita masih sangat bergantung pada orang tua, terutama ibu. Banyak faktor orang tua yang berhubungan dengan stunting, antara lain pendidikan, pekerjaan, dan pengetahuan gizi orang tua, serta jumlah anggota keluarga. ${ }^{6-11}$ Beberapa faktor orang tua ini berkaitan dengan pembagian makanan dalam keluarga yang akhirnya mempengaruhi jumlah asupan balita. Beberapa penelitian menyatakan asupan makanan berkaitan dengan stunting pada balita. ${ }^{12-14}$

Prevalensi stunting pada balita di Indonesia cukup mengkhawatirkan. Secara nasional prevalensi stunting tahun 2018 sebesar 30,8\%. ${ }^{15}$ World Health Organization (WHO) menetapkan angka masalah kesehatan masyarakat tidak melebihi 20\%. Dengan demikian Indonesia termasuk dalam negara yang bermasalah dengan kesehatan masyarakat. ${ }^{16}$ Hasil Riset Kesehatan Dasar (Riskesdas) tahun 2018 menunjukkan prevalensi stunting pada balita sebesar $42,7 \%$ di NTT, sedangkan di Kabupaten Kupang $41,43 \% .{ }^{15}$ Penelitian ini bertujuan untuk menganalisis faktor-faktor yang berhubungan dengan kejadian stunting pada balita di Desa Kairane dan Desa Fatukanutu, Kecamatan Amabi Oefeto, Kabupaten Kupang.

\section{Metode}

Penelitian ini menggunakan desain cross sectional. Proses pengumpulan, pengolahan, dan analisis data dilakukan pada bulan September sampai Desember 2019 di Desa Kairane dan Desa Fatukanutu, Kecamatan Amabi Oefeto, Kabupaten Kupang. Alasan pemilihan kedua desa ini adalah lokasi kedua desa ini yang berada dekat dengan pusat pemerintahan kecamatan sehingga akses terhadap pelayanan publik dan kesehatan lebih mudah. Desa Fatukanutu merupakan ibukota Kecamatan Amabi Oefeto, sedangkan Desa Kairane berlokasi dekat dengan Desa Fatukanutu. Populasi penelitian adalah seluruh balita berusia 059 bulan yang berada di Desa Kairane dan Desa Fatukanutu dengan jumlah 223 orang. Sampel penelitian berjumlah 176 orang, dengan rincian Desa Kairane 44 balita dan Desa Fatukanutu 132 balita, yang dipilih dengan teknik pengambilan sampel acak (simple random sampling). 
Pemilihan sampel berdasarkan kriteria inklusi dan eksklusi. Kriteria inklusi dalam penelitian ini adalah balita berusia 0-59 bulan, bertempat tinggal di lokasi penelitian, dan bersedia ikut dalam penelitian. Kriteria eksklusi adalah balita mengalami sakit dan tidak berada di rumah saat pengambilan data.

Variabel penelitian meliputi variabel bebas dan variabel terikat. Variabel bebas meliputi karakteristik orang tua dan asupan zat gizi. Karakteristik orang tua meliputi pendidikan dan pekerjaan orang tua, pengetahuan gizi ibu, dan jumlah anggota keluarga. Variabel asupan zat gizi meliputi protein, lemak, dan karbohidrat. Variabel terikat, yaitu stunting yang diperoleh dengan pengukuran tinggi atau panjang badan. Panjang badan diukur menggunakan length board, sedangkan tinggi badan menggunakan microtoise. Umur balita ditentukan dengan melihat buku KIA. Selanjutnya dihitung menggunakan indikator $\mathrm{TB} / \mathrm{U}$ atau $\mathrm{PB} / \mathrm{U}$ dengan software WHO Anthro. Balita dikategorikan stunting apabila nilai z-score $<-2$ SD. Data orang tua diperoleh menggunakan kuesioner. Data asupan zat gizi diperoleh dengan mewawancarai ibu balita tentang makanan yang dikonsumsi balita menggunakan form food recall 1x24 jam. Food recall 1x24 jam dapat digunakan untuk mengetahui asupan ratarata satu kelompok atau lebih.

Data pendidikan orang tua dibagi dalam kategori tidak tamat SD, tamat SD, tamat SMP, tamat SMA, dan tamat perguruan tinggi. Data pekerjaan ayah dibagi dalam kategori PNS/TNI/Polri, pegawai swasta, wiraswasta, buruh, dan petani, sedangkan pekerjaan ibu dikelompokkan berdasarkan pekerjaan pegawai swasta, petani, dan tidak bekerja (ibu rumah tangga). Data jumlah anggota keluarga dibagi dalam 2 kelompok, yaitu $\leq 4$ orang dan $>4$ orang, sedangkan pengetahuan gizi ibu dibagi menjadi tingkat pengetahuan baik dan kurang. Data asupan zat gizi diolah menggunakan aplikasi Nutrisurvey, kemudian dibandingkan dengan Angka Kecukupan Gizi (AKG) 2013 dan dikelompokkan menjadi asupan kurang dan baik. Asupan kurang jika $\leq 80 \%$ AKG dan asupan baik jika $>80 \%$ AKG. Teknik analisis data yang digunakan adalah analisi univariat dan bivariat. Analisis univariat digunakan untuk melihat distribusi frekuensi dari variabel yang diteliti. Analisis bivariat digunakan untuk melihat hubungan faktor orang tua dan asupan zat gizi dengan stunting pada balita menggunakan uji chi square pada batas nilai $\mathrm{p}$ value sebesar 0,05 .

\section{Hasil}

Tabel 1 menjelaskan bahwa sebagian besar ibu tidak bekerja $(84,1 \%)$ sedangkan ayah paling banyak bekerja sebagai petani $(78,7 \%)$. Tingkat pendidikan ibu rendah karena sebagian besar ibu berpendidikan sekolah dasar $(53,4 \%)$, selaras dengan tingkat pengetahuan gizi ibu yang tergolong kurang (56,3\%). Pendidikan ayah lebih baik dibandingkan ibu karena lebih banyak ayah berpendidikan SMA $(30,7 \%)$. Lebih banyak keluarga yang memiliki anggota keluarga $\leq 4$ orang $(52,3 \%)$. Lebih banyak balita yang asupan karbohidrat, protein, dan lemak berada dalam kategori baik (>80\%AKG).

Tabel 2 menunjukkan sebagian besar ibu tidak bekerja (ibu rumah tangga), baik pada balita stunting $(82,4 \%)$ maupun tidak stunting $(85,3 \%)$. Hasil uji statistik menunjukkan pekerjaan ibu tidak berhubungan dengan stunting pada balita. Sebagian besar ibu balita stunting $(67,6 \%)$ dan tidak stunting $(43,1 \%)$ menyelesaikan pendidikan dasar (sekolah dasar). Hasil uji statistik menunjukkan pendidikan ibu berhubungan signifikan dengan stunting pada balita.

Faktor ayah yang diteliti dalam penelitian ini adalah pekerjaan dan pendidikan ayah. Semua ayah paling banyak bekerja sebagai petani. Berdasarkan tingkat pendidikan, ayah 
Tabel 1. Distribusi Frekuensi Variabel yang Diteliti

\begin{tabular}{|c|c|c|c|}
\hline Variabel & Kategori & $\mathbf{n}$ & $\%$ \\
\hline \multirow[t]{4}{*}{ Pekerjaan Ibu } & Tidak bekerja (Ibu rumah tangga) & 148 & 84,1 \\
\hline & Pegawai swasta & 3 & 1,7 \\
\hline & Petani & 18 & 10,2 \\
\hline & Lainnya & 7 & 4,0 \\
\hline \multirow[t]{6}{*}{ Pekerjaan Ayah } & PNS/TNI/Polri & 8 & 4,5 \\
\hline & Pegawai swasta & 6 & 3,4 \\
\hline & Wiraswasta & 10 & 5,7 \\
\hline & Buruh & 11 & 6,3 \\
\hline & Petani & 135 & 76,7 \\
\hline & Lainnya & 6 & 3,4 \\
\hline \multirow[t]{5}{*}{ Pendidikan Ibu } & Tidak Tamat SD & 7 & 4,0 \\
\hline & Tamat SD & 94 & 53,4 \\
\hline & Tamat SMP & 27 & 15,3 \\
\hline & Tamat SMA & 40 & 22,7 \\
\hline & Tamat Perguruan Tinggi & 8 & 4,5 \\
\hline \multirow[t]{5}{*}{ Pendidikan Ayah } & Tidak Tamat SD & 8 & 4,5 \\
\hline & Tamat SD & 50 & 28,4 \\
\hline & Tamat SMP & 52 & 29,5 \\
\hline & Tamat SMA & 54 & 30,7 \\
\hline & Tamat Perguruan Tinggi & 12 & 6,8 \\
\hline \multirow[t]{2}{*}{ Pengetahuan Gizi Ibu } & Baik & 77 & 43,8 \\
\hline & Kurang & 99 & 56,3 \\
\hline \multirow[t]{2}{*}{ Jumlah Anggota Keluarga } & $\leq 4$ orang & 92 & 52,3 \\
\hline & $>4$ orang & 84 & 47,7 \\
\hline \multirow[t]{2}{*}{ Karbohidrat } & Baik (>80\%AKG) & 92 & 52,3 \\
\hline & Kurang $(\leq 80 \% \mathrm{AKG})$ & 84 & 47,7 \\
\hline \multirow[t]{2}{*}{ Protein } & Baik $(>80 \%$ AKG) & 100 & 56,8 \\
\hline & Kurang $(\leq 80 \% \mathrm{AKG})$ & 76 & 43,2 \\
\hline \multirow[t]{2}{*}{ Lemak } & Baik $(>80 \% A K G)$ & 97 & 55,1 \\
\hline & Kurang $(\leq 80 \% \mathrm{AKG})$ & 79 & 44,9 \\
\hline
\end{tabular}

balita stunting lebih banyak berpendidikan tamat sekolah dasar $(39,2 \%)$, sedangkan ayah balita tidak stunting lebih banyak berpendidikan tamat SMP $(35,3 \%)$. Hasil uji menunjukkan pendidikan ayah berhubungan dengan stunting pada balita, sedangkan pekerjaan ayah tidak berhubungan.

Pada ibu yang memiliki balita stunting, lebih banyak berpengetahuan gizi rendah $(66,2 \%)$. Sedangkan pada ibu yang memiliki balita tidak stunting, lebih banyak yang berpengetahuan gizi baik $(60,8 \%)$. Pada penelitian ini, lebih banyak balita stunting memiliki anggota keluarga $\geq 4$ orang $(59,5 \%)$. Hasil uji statistik menunjukkan pengetahuan gizi ibu dan jumlah anggota keluarga berhubungan signifikan dengan stunting pada balita. Asupan karbohidrat, protein, dan lemak balita tidak stunting lebih baik dibandingkan balita stunting. Hasil uji statistik menunjukkan asupan karbohidrat tidak berhubungan signifikan dengan stunting pada balita, sedangkan asupan protein dan lemak berhubungan signifikan (Tabel 2).

\section{Pembahasan}

Penelitian ini menunjukkan lebih banyak ibu yang tidak bekerja. Penelitian Batiro et al., di Ethiopia mengemukakan hasil yang sama. ${ }^{17}$ Kebanyakan ibu tidak bekerja karena sebagian besar masyarakat masih menganggap tugas utama ibu adalah mengurus rumah tangga. Pekerjaan ayah dalam penelitian ini cukup bervariasi, tetapi yang paling dominan adalah petani. Hal ini dikarenakan sebagian besar rumah tangga di lokasi penelitian memiliki lahan pertanian. Hasil ini sama dengan penelitian di Burkina Faso dan Ethiopia. ${ }^{5,18}$ Dalam 
Tabel 2. Faktor-faktor yang Berhubungan dengan Stunting

\begin{tabular}{|c|c|c|c|c|c|c|}
\hline \multirow{3}{*}{ Variabel } & \multirow{3}{*}{ Kategori } & \multicolumn{4}{|c|}{ Stunting } & \multirow{3}{*}{ Pvalue } \\
\hline & & \multicolumn{2}{|c|}{ Ya } & \multicolumn{2}{|c|}{ Tidak } & \\
\hline & & $\mathbf{n}$ & $\%$ & n & $\%$ & \\
\hline \multicolumn{7}{|l|}{ Faktor orang tua } \\
\hline \multirow[t]{4}{*}{ Pekerjaan Ibu } & $\begin{array}{l}\text { Tidak bekerja (Ibu rumah } \\
\text { tangga) }\end{array}$ & 61 & 82,4 & 87 & 85,3 & 0,895 \\
\hline & Pegawai swasta & 1 & 1,4 & 2 & 2,0 & \\
\hline & Petani & 9 & 12,2 & 9 & 8,8 & \\
\hline & Lainnya & 3 & 4,1 & 4 & 3,9 & \\
\hline \multirow[t]{6}{*}{ Pekerjaan Ayah } & PNS/TNI/Polri & 4 & 5,4 & 4 & 3,9 & 0,233 \\
\hline & Pegawai swasta & 1 & 1,4 & 5 & 4,9 & \\
\hline & Wiraswasta & 3 & 4,1 & 7 & 6,9 & \\
\hline & Buruh & 8 & 10,8 & 3 & 2,9 & \\
\hline & Petani & 56 & 75,7 & 79 & 77,5 & \\
\hline & Lainnya & 2 & 2,7 & 4 & 3,9 & \\
\hline \multirow[t]{5}{*}{ Pendidikan Ibu } & Tidak Tamat SD & 2 & 2,7 & 5 & 4,9 & $0,031 *$ \\
\hline & Tamat SD & 50 & 67,6 & 44 & 43,1 & \\
\hline & Tamat SMP & 7 & 9,5 & 20 & 19,6 & \\
\hline & Tamat SMA & 12 & 16,2 & 28 & 27,5 & \\
\hline & Tamat Perguruan Tinggi & 3 & 4,1 & 5 & 4,9 & \\
\hline \multirow[t]{5}{*}{ Pendidikan Ayah } & Tidak Tamat SD & 5 & 6,8 & 3 & 2,9 & $0,035^{*}$ \\
\hline & Tamat SD & 29 & 39,2 & 21 & 20,6 & \\
\hline & Tamat SMP & 16 & 21,6 & 36 & 35,3 & \\
\hline & Tamat SMA & 19 & 25,7 & 35 & 34,3 & \\
\hline & Tamat Perguruan Tinggi & 5 & 6,8 & 7 & 6,9 & \\
\hline \multirow[t]{2}{*}{ Pengetahuan Gizi Ibu } & Baik & 25 & 33,8 & 59 & 51,0 & $0,002 *$ \\
\hline & Kurang & 49 & 66,2 & 43 & 49,0 & \\
\hline \multirow[t]{2}{*}{ Jumlah Anggota Keluarga } & $\leq 4$ orang & 30 & 40,5 & 62 & 60,8 & $0,008 *$ \\
\hline & $>4$ orang & 44 & 59,5 & 40 & 39,2 & \\
\hline \multicolumn{7}{|l|}{ Asupan Zat Gizi } \\
\hline \multirow[t]{2}{*}{ Karbohidrat } & Baik (>80\%AKG) & 40 & 54,1 & 52 & 51,0 & 0,687 \\
\hline & Kurang $(\leq 80 \% \mathrm{AKG})$ & 34 & 45,9 & 50 & 49,0 & \\
\hline \multirow[t]{2}{*}{ Protein } & Baik (>80\%AKG) & 32 & 43,2 & 68 & 66,7 & $0,002 *$ \\
\hline & Kurang $(\leq 80 \% \mathrm{AKG})$ & 42 & 56,8 & 34 & 33,3 & \\
\hline \multirow[t]{2}{*}{ Lemak } & Baik (>80\%AKG) & 33 & 44,6 & 64 & 62,7 & $0,017 *$ \\
\hline & Kurang $(\leq 80 \% \mathrm{AKG})$ & 41 & 55,4 & 38 & 37,3 & \\
\hline
\end{tabular}

Keterangan : *=Bermakna secara statistik pada alpha $(\alpha) 0,05$

penelitian ini, pekerjaan orang tua tidak berhubungan signifikan dengan kejadian stunting pada balita. Hal ini dapat disebabkan oleh pekerjaan ayah dan ibu didominasi oleh satu pekerjaan saja. Penelitian di Tanzania dan Ethiopia menemukan hasil yang sama. ${ }^{19,20}$

Hasil uji statistik menunjukkan pendidikan ayah dan ibu berhubungan signifikan dengan stunting pada balita. Hasil penelitian di Tanzania dan Bangladesh menunjukkan pendidikan orang tua berhubungan dengan kejadian stunting pada balita. ${ }^{7,21}$ Pendidikan orang tua, terutama ibu, cukup berperan karena ibu yang berpendidikan lebih sadar kondisi kesehatan anak. ${ }^{7}$ Pendidikan orang tua, baik ayah maupun ibu, yang rendah dapat menyebabkan pemahaman yang kurang tentang kesehatan anak dan telah ditemukan keterkaitan dengan masalah gizi pada balita. Orang tua yang kurang berpendidikan kemungkinan kesulitan dalam memahami informasi kesehatan. ${ }^{22}$

Penelitian di Madagaskar dan Somalia menemukan bahwa jumlah anggota keluarga berhubungan dengan kejadian stunting. ${ }^{23,24}$ Hal ini dapat disebabkan karena berkurangnya persediaan makanan dan adanya kompetisi untuk mendapatkan makanan. ${ }^{25}$ Penelitian di Nigeria menunjukkan pengetahuan ibu 
tentang gizi berhubungan dengan status stunting pada balita. Rendahnya pengetahuan gizi dapat mengakibatkan rendahnya asupan zat gizi. ${ }^{26}$

Hasil penelitian menunjukkan asupan protein dan lemak berhubungan signifikan dengan kejadian stunting pada balita. Penelitian lain di Sulawesi Selatan dan Jawa Timur menunjukkan hasil yang sama. $^{27,28}$ Asupan protein menyediakan asam amino yang diperlukan tubuh untuk membangun matriks tulang dan mempengaruhi pertumbuhan tulang karena protein berfungsi untuk memodifkasi sekresi dan aksi osteotropic hormone IGFI, sehingga, asupan protein dapat memodulasi potensi genetik dari pencapaian peak bone mass. Asupan protein rendah terbukti merusak akuisisi mineral massa tulang dengan merusak produksi dan efek IGF-I. IGF-I mempengaruhi pertumbuhan tulang dengan merangsang proliferasi dan diferensiasi kondrosit di lempeng epifsis pertumbuhan dan langsung mempengaruhi osteoblast. $^{13}$

Penelitian di Sulawesi Selatan menunjukkan asupan lemak berhubungan dengan stunting pada balita. ${ }^{29}$ Hal ini dikarenakan dalam lemak terkandung asam lemak esensial yang memiliki peran dalam mengatur kesehatan. Selain itu simpanan energi dapat berasal dari konsumsi lemak dan lemak sebagai alat pengangkut dan pelarut vitamin larut lemak dalam tubuh dimana fungsi-fungsi tersebut sangat mempengaruhi pertumbuhan balita. ${ }^{12}$ Pada penelitian ini, asupan karbohidrat tidak berhubungan signifikan dengan stunting pada balita. Hal ini disebabkan oleh lebih banyak balita stunting yang mengkonsumsi karbohidrat dalam kategori baik dibandingkan kategori kurang. Fungsi utama karbohidrat adalah penghasil energi dan tidak berkaitan dengan pembentukan tulang dan jaringan baru. ${ }^{30}$

\section{Kesimpulan}

Hasil penelitian menunjukkan pendidikan ayah dan ibu, jumlah anggota keluarga, dan pengetahuan gizi ibu, serta asupan protein dan karbohidrat berhubungan signifikan dengan kejadian stunting pada balita. Sedangkan pekerjaan ayah dan ibu, serta asupan karbohidrat tidak berhubungan. Hasil penelitian ini dapat digunakan oleh instansi terkait untuk melakukan berbagai tindakan intervensi untuk mencegah dampak jangka panjang stunting pada balita. Tindakan intervensi dapat dilakukan dengan meningkatkan pengetahuan gizi ibu dan asupan makanan balita. Pemerintah setempat melalui tenaga kesehatan dapat melakukan penyuluhan dan konseling bagi ibu balita tentang gizi seimbang. Selain itu, ibu-ibu dapat diajarkan pengolahan pangan lokal yang murah dan mudah didapat, serta bernilai gizi tinggi.

\section{Daftar Pustaka}

1. Rosmalina Y, Luciasari E, Aditianti A, Ernawati F. Upaya Pencegahan Dan Penanggulangan Batita Stunting: Systematic Review. Gizi Indones. 2018;41(1):1-14.

2. Humphrey JH, Mbuya MNN, Ntozini R, Moulton LH, Stoltzfus RJ, Tavengwa N V., et al. Independent and combined effects of improved water, sanitation, and hygiene, and improved complementary feeding, on child stunting and anaemia in rural Zimbabwe: a cluster-randomised trial. Lancet Glob Heal [Internet]. 2019;7(1):e132-47. Available from:

https://www.sciencedirect.com/science/article/ pii/S2214109X18303747

3. Leroy JL, Frongillo EA. Perspective: What Does Stunting Really Mean? A Critical Review of the Evidence. Adv Nutr [Internet]. 2019;10(2):196-204. Available from: https://academic.oup.com/advances/article/10/ 2/196/5364423

4. Martorell R. Improved nutrition in the first 1000 days and adult human capital and health. Am J Hum Biol [Internet]. 2017;29(2):1-24. Available from: https://www.ncbi.nlm.nih.gov/pmc/articles/P MC5761352/

5. Fregonese F, Siekmans K, Kouanda S, Druetz $\mathrm{T}$, Ly A, Diabaté $\mathrm{S}$, et al. Impact of contaminated household environment on stunting in children aged 12-59 months in Burkina Faso. J Epidemiol Community Health [Internet]. 2017;71(4):356-63. Available from:

www.academia.edu/download/55321906/2016 
Fregonese_JECH.pdf

6. Rachmi CN, Agho KE, Li M, Baur LA. Stunting, underweight and overweight in children aged 2.0-4.9 years in Indonesia: Prevalence trends and associated risk factors. PLoS One [Internet]. 2016;11(5):1-17. Available from: https://www.ncbi.nlm.nih.gov/pmc/articles/P MC4864317/

7. Chirande L, Charwe D, Mbwana H, Victor R, Kimboka S, Issaka AI, et al. Determinants of stunting and severe stunting among underfives in Tanzania: evidence from the 2010 cross-sectional household survey. BMC Pediatr [Internet]. 2015;15(1):165-78. Available from: http://dx.doi.org/10.1186/s12887-015-0482-9

8. Akombi BJ, Agho KE, Hall JJ, Wali N, Renzaho AMN, Merom D. Stunting, wasting and underweight in Sub-Saharan Africa: A systematic review. Int $\mathbf{J}$ Environ Res Public Health [Internet]. 2017;14(8):1-18. Available from: https://www.mdpi.com/16604601/14/8/863

9. Beal T, Tumilowicz A, Sutrisna A, Izwardy D, Neufeld LM. A review of child stunting determinants in Indonesia. Matern Child Nutr. 2018;14(4):1-10.

10. Siti Rahayu KN, Ni'mah. Faktor yang berhubungan dengan kejadian. Media Gizi Indones [Internet]. 2015;10(1):13-9. Available from: https://ejournal.unair.ac.id/MGI/article/download/311 $7 / 2264$

11. Setiawan E, Machmud R, Masrul M. FaktorFaktor yang Berhubungan dengan Kejadian Stunting pada Anak Usia 24-59 Bulan di Wilayah Kerja Puskesmas Andalas Kecamatan Padang Timur Kota Padang Tahun 2018. J Kesehat Andalas. 2018;7(2):275-84.

12. Ulul Azmy, Luki Mundiastuti. Konsumsi Zat Gizi pada Balita Stunting dan Non-Stunting di Kabupaten Bangkalan. Amerta Nutr. 2018;2(3):292-8.

13. Sari EM, Juffrie M, Nurani N, Sitaresmi MN. Asupan protein, kalsium dan fosfor pada anak stunting dan tidak stunting usia 24-59 bulan. J Gizi Klin Indones [Internet]. 2016;12(4):152. Available from: http://repository.usahid.ac.id/402/

14. Damayanti RA, Muniroh L, Farapti F. Perbedaan Tingkat Kecukupan Zat Gizi Dan Riwayat Pemberian Asi Eksklusif Pada Balita Stunting Dan Non Stunting. Media Gizi Indones. 2017;11(1):61-9.

15. Kementerian Kesehatan RI Badan Penelitian dan Pengembangan. Laporan Hasil Riset Kesehatan Dasar (Riskesdas) Indonesia tahun 2018. Riset Kesehatan Dasar. Jakarta; 2018.

16. Aryastami NK. Kajian Kebijakan dan
Penanggulangan Masalah Gizi Stunting di Indonesia. Bul Penelit Kesehat [Internet]. 2017;45(4):233-40. Available from: ejournal.litbang.depkes.go.id/index.php/BPK/ article/download/7465/5434

17. Batiro B, Demissie T, Halala Y, Anjulo AA. Determinants of stunting among children aged 6-59 months at Kindo Didaye woreda, Wolaita Zone, Southern Ethiopia: Unmatched case control study. PLoS One [Internet]. 2017;12(12):1-15. Available from: https://www.ncbi.nlm.nih.gov/pmc/articles/P MC5737969/

18. Desalegn BB, Kinfe E, Fikre K, Bosha T. Stunting and Its Associated Factors in Under Five Years Old Children: The Case of Hawassa University Technology Villages, Southern Ethiopia. IOSR J Environ Sci Toxicol Food Technol [Internet]. 2016;10(11):25-31. Available from: https://pdfs.semanticscholar.org/2e25/65d5a96 c13e63ccfe374594909e075123234.pdf

19. Mgongo M, Chotta NAS, Hashim TH, Uriyo JG, Damian DJ, Stray-Pedersen B, et al. Underweight, stunting and wasting among children in Kilimanjaro region, Tanzania; a population-based cross-sectional study. Int $\mathbf{J}$ Environ Res Public Health [Internet]. 2017;14(5):1-12. Available from: https://www.mdpi.com/1660-4601/14/5/509

20. Beminet Moges, Amsalu Feleke, Solomon Meseret FD. Magnitude of Stunting and Associated Factors Among 6-59 Months Old Children in Hossana Town, Southern Ethiopia. J Clin Res Bioeth [Internet]. 2015;06(01):4-11. Available from: www.academia.edu/download/48672453/mag nitude-of-stunting-and-associated-factorsamong-months-old-children-21559627.1000207_1.pdf

21. Sarma H, Khan JR, Asaduzzaman M, Uddin F, Tarannum S, Hasan MM, et al. Factors Influencing the Prevalence of Stunting Among Children Aged Below Five Years in Bangladesh. Food Nutr Bull [Internet]. 2017;38(3):291-301. Available from: https://journals.sagepub.com/doi/full/10.1177/ 0379572117710103

22. Khattak UK, Iqbal SP, Ghazanfar H. The Role of Parents' Literacy in Malnutrition of Children Under the Age of Five Years in a Semi-Urban Community of Pakistan: A CaseControl Study. Cureus [Internet]. 2017;9(6). Available from: https://www.ncbi.nlm.nih.gov/pmc/articles/P MC5498125/

23. Rakotomanana H, Gates GE, Hildebrand D, Stoecker BJ. Determinants of stunting in children under 5 years in Madagascar. Matern Child Nutr. 2017;13(4). 
24. Kinyoki DK, Berkley JA, Moloney GM, Kandala NB, Noor AM. Predictors of the risk of malnutrition among children under the age of 5 years in Somalia. Public Health Nutr. 2015;18(17):3125-33.

25. Ntshebe O, Channon AA, Hosegood V. Household composition and child health in Botswana. BMC Public Health [Internet]. 2019;19(1):1-13. Available from: https://link.springer.com/article/10.1186/s128 89-019-7963-y

26. Omaghomi Jemide J, Nkechi Ene-Obong H, Effiong Edet E, Emmanuel Udoh E, Julie Omaghomi Jemide C. Association of maternal nutrition knowledge and child feeding practices with nutritional status of children in Calabar South Local Government Area, Cross River State, Nigeria. Int J Home Sci [Internet]. 2016;2(1):293-8. Available from: www.homesciencejournal.com

27. Rauf S, Hendrayati. Various Factors in Stunting Children Aged 12 to 60 Months. Heal Notions [Internet]. 2019;3(9):374-9. Available

from: http://www.heanoti.com/index.php/hn/article/ download/hn30902/30902

28. Mahmudiono T, Sumarmi S, Rosenkranz RR. Household dietary diversity and child stunting in East Java, Indonesia. Asia Pac J Clin Nutr [Internet]. 2017;26(2):317-25. Available from:

https://search.informit.com.au/documentSum mary; $\mathrm{dn}=688058173877148$;res=IELHEA

29. Hendrayati H, Asbar R. Analisis Faktor Determinan Kejadian Stunting Pada Balita Usia 12 Sampai 60 Bulan. Media Gizi Pangan [Internet]. 2018;25(1):69-76. Available from: https://www.neliti.com/publications/265331/a nalisis-faktor-determinan-kejadian-stuntingpada-balita-usia-12-sampai-60-bulan

30. Simorangkir EA, Panggabean SP, Sudaryati E. Relationship between Caries Experience and Food Intake with Stunting Among 6-8-Years Old of Elementary School at Pantai Labu In 2018. Britain Int Exact Sci J [Internet]. 2020;2(1):313-9. Available from: http://biarjournal.com/index.php/bioex/article/ view/152 